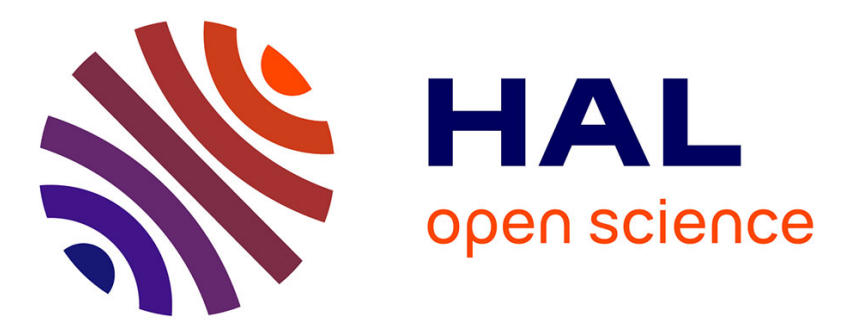

\title{
A Novel Five-Phase Fractional Slot Concentrated Winding with Low Space Harmonic Contents
}

B. Zhao, J. Gong, T. Tong, Y. Xu, E. Semail, N. -K. Nguyen, F. Gillon

\section{To cite this version:}

B. Zhao, J. Gong, T. Tong, Y. Xu, E. Semail, et al.. A Novel Five-Phase Fractional Slot Concentrated Winding with Low Space Harmonic Contents. IEEE Transactions on Magnetics, 2021, 57 (6), pp.5. 10.1109/tmag.2021.3057650 . hal-03335270

\section{HAL Id: hal-03335270 https://hal.science/hal-03335270}

Submitted on 6 Sep 2021

HAL is a multi-disciplinary open access archive for the deposit and dissemination of scientific research documents, whether they are published or not. The documents may come from teaching and research institutions in France or abroad, or from public or private research centers.
L'archive ouverte pluridisciplinaire HAL, est destinée au dépôt et à la diffusion de documents scientifiques de niveau recherche, publiés ou non, émanant des établissements d'enseignement et de recherche français ou étrangers, des laboratoires publics ou privés. 


\title{
A Novel Five-Phase Fractional Slot Concentrated Winding with Low Space Harmonic Contents
}

\author{
B. Zhao ${ }^{1}$, J. Gong ${ }^{\circledR 1}$, T. Tong ${ }^{1,2}$, Y. Xu ${ }^{\circledR 1}$, E. Semail ${ }^{\circledR 3}$, N.-K. Nguyen ${ }^{\circledR 3}$, and F. Gillon ${ }^{3}$ \\ ${ }^{1}$ School of Electrical Engineering, Shandong University, Jinan 250061, China \\ ${ }^{2}$ HEI, EA 2697-L2EP-Laboratoire d'Electrotechnique et d'Electronique de Puissance, Univ. Lille, Arts et Métiers ParisTech, \\ Centrale Lille 59000 Lille, France \\ ${ }^{3}$ State Grid Jiangxi Electric Power Research Institute, Nanchang 330096, China
}

In this article, a novel five-phase fractional-slot concentrated winding (FSCW) with 20-slot/22-pole is presented. It benefits not only the advantages of conventional FSCW but also weak space harmonics of magnetomotive force (MMF). The winding allows eliminating the first sub-order harmonic. The new layout of the winding topology is obtained by a combination of stator shift technique of the winding in the slots with a special coupling of the windings (star-pentagon), using winding function theory. The high performances of the new winding layout are validated using the finite element method (FEM). Compared to the conventional winding, the winding factor and the total harmonic distortion (THD) of MMF are improved by $1.3 \%$ and $2.2 \%$, respectively. With the same injection of current density, the average output torque is increased by $1 \%$ and the torque ripple is decreased by $60 \%$. The eddy current losses in the permanent magnets (PMs) at rated speed $(600 \mathrm{r} / \mathrm{min})$ and $2100 \mathrm{r} / \mathrm{min}$ speed are improved by $67 \%$ and $56 \%$, respectively.

Index Terms-5-phase permanent magnet (PM) machine, finite element analysis, low-harmonic contents.

\section{INTRODUCTION}

$\mathbf{F}$ RACTIONAL-SLOT concentrated winding (FSCW) are widely applied in electrical machines, due to the advantages of short end windings, high power density, high efficiency, high slot-filling factor, small cogging torque, etc., [1], [2]. Numerous commercial three-phase traction motors with FSCW can be found, such as Honda (24 slots/16 poles), Bosch (36 slots/ 24 poles), Hyundai (24 slots/16 poles), and Toyota (12 slots/8 poles). In the case of multiphase machines, more choices of slot/pole combinations of FSCW can be made, which provides more possibilities for the requirement of the machine performance [1].

One of the main challenges of FSCW is the rich content of space harmonics of magnetomotive force (MMF), including both sub- and high-orders. These parasite harmonics can lead to local core saturation [3], Eddy current loss, vibration and noise, etc., which deteriorate the performance of the machine, especially for high-speed applications. Therefore, many research studies have been made to avoid the bad selection of slot/pole combinations [4], [5]. In addition, to furtherly reduce or eliminate parasitic harmonics of classical slot/pole combinations of FSCW, various techniques have been proposed [6]. Stator shifting method is the most common one, which can significantly reduce the loss-producing harmonics and improve the flux weakening performance by extending the one slot coil pitch to two slots [7]-[9]. The effectiveness of this method was also validated with multiphase machines in [10] and [11]. Unfortunately, the end-winding is overlapped, which makes the winding production more complex. Unequal tooth widths technique is proposed in [12] and [13] and

Manuscript received November 30, 2020; revised December 29, 2020 and January 28, 2021; accepted January 31, 2021. Date of publication February 8, 2021; date of current version May 17, 2021. Corresponding author: J. Gong (e-mail: gongjinlin@sdu.edu.cn).

Color versions of one or more figures in this article are available at https://doi.org/10.1109/TMAG.2021.3057650.

Digital Object Identifier 10.1109/TMAG.2021.3057650 integrated with an optimization algorithm for the winding design in [14] and [15]. A higher number of layers $(\geq 3)$ can also be used for the reduction of dominant loss-producing harmonics [16], [17]. However, with the increase of the layer number, the winding becomes more complex to realize. In this article, based on the stator shift technique but with the endwinding non-overlapping, a new topology of five-phase FSCW with selective harmonic elimination is proposed by combining the star and pentagon coils connection [18]. This method can also be extended to any number of phase winding design.

This article will be organized as follows. In Section II, the basic structure of the traditional five-phase 20-slot/ 22-pole winding with MMF harmonics presentation is introduced, and the derivation process of the proposed new winding topology layout using winding shift technology is introduced. In Section III, the finite element method (FEM) is used to verify the high performance of machines with the proposed winding topology.

\section{Derivation Process of NeW Winding With LOW MMF HARMONIC CONTENTS}

\section{A. Conventional 20-Slot/22-Pole Winding}

For electrical machines with FSCW, the relationship between the slot number $(Q)$ and the pole number $(2 p)$, i.e., $2 p=Q \pm 2$, is often satisfied to obtain high flux linkage and torque density. Therefore, a five-phase winding topology in [19] is chosen here as a reference to present the new method, which can be used to eliminate the parasite harmonics of MMF. The method can be easily extended to other similar slot/pole combinations of different phases. Fig. 1(a) shows the structures of the outer-rotor 5-phase/20-slot/22-pole permanent magnet synchronous machines (PMSMs) with conventional winding configuration, which can be used for in-wheel traction application. The windings of different phases are distinguished by color and the A-phase winding is marked as an example. It can be noted that the winding of each phase consists of four coils which can be connected in series or parallel. 




(a)

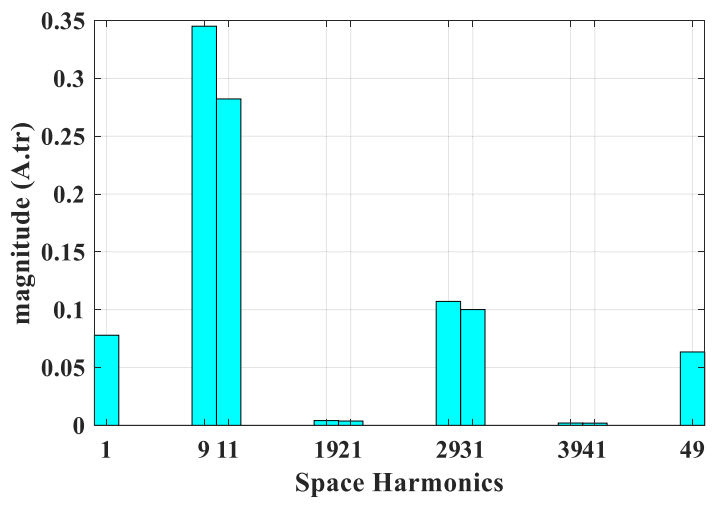

(b)

Fig. 1. 5-phase/20-slots/22-poles conventional winding. (a) Conventional layout. (b) MMF harmonics [20].

The MMF of this winding topology is analyzed using winding function theory and shown in Fig. 1(b). It can be seen that the amplitude of the sub- and sup-harmonics are important compared to the working harmonic (11th). These harmonics of MMF rotate in the air gap with different speeds inducing eddy-currents and causing losses not only on the stator but also on the permanent magnets (PMs) on the rotor, local saturation and torque ripple, etc., which are expected to be as small as possible.

\section{B. Proposal of New Layout of 20-Slot/ 22-Pole Winding}

To eliminate or reduce the parasitic harmonics, the conventional winding configuration of each phase can be split into two sub-windings A1 and A2 as shown in Fig. 1(a), and each sub-winding consists of two coils. Considering the injection of fundamental current, the $v$ th MMF harmonic of sub-winding A1 is expressed as

$$
f_{1 v}=\frac{5 k_{w} N I}{\pi v} \cos (\omega t \mp v \theta)
$$

where $k_{w}$ is the winding factor, $N$ is the effective number of turns of each coil around tooth, $I$ is the rms value of the current, $\omega$ is the angular velocity, $\theta$ is the initial angle, the harmonics rotating in the same direction as the working harmonic as are with "-," and the reverses are with "+."

Now the new stator shift technique is applied to the conventional configuration. Supposing that the sub-winding A2 is shifted by a mechanical angle $\delta$, and the injected current is shifted by an electrical angle $\phi$, the $v$ th MMF harmonic of the sub-winding 2 can be expressed as

$$
f_{2 v}=\frac{5 k N I}{\pi v} \cos [(\omega t-\phi) \mp v(\theta-\delta)] .
$$

Combining (1) and (2), the $v$ th harmonic of the total MMF can be then expressed as

$$
f_{v}=\frac{5 k N I}{\pi v} \cdot 2 \cdot \cos \left(\frac{\phi \mp v \delta}{2}\right) \cos \left[\left(\omega t-\frac{\phi}{2}\right)-v\left(\theta-\frac{\delta}{2}\right)\right] \text {. }
$$

According to (3), a distribution factor of the $v$ th harmonic of MMF is defined in the following equation:

$$
k_{v}=\cos \left(\frac{\phi \mp v \delta}{2}\right) .
$$

The distribution factor of working harmonic can be designed to be 1 , i.e., $k_{11}=1$, and the ones of the other parasite harmonics can be selectively eliminated by designing $k_{v}$. In this article, the first harmonic is first chosen to eliminate, i.e., $k_{1}=0$, and the following relationship can be obtained:

$$
\begin{aligned}
\phi-11 \delta & =2 k \pi, \text { with } k_{11}=1 \\
\phi-\delta & =(2 k+1) \pi, \text { with } k_{1}=0 .
\end{aligned}
$$

Since the shifted mechanical angle $\delta$ should be integral multiple of the slot angle $\left(360^{\circ} / 20=18^{\circ}\right)$, the optimal angle $\delta_{\text {optim }}$ is equal to $126^{\circ}$, i.e., the sub-winding 2 is shifted seven slots compared to the sub-winding 1 . In this case, the phase difference of the currents between these two sub-windings is $\phi_{\text {optim }}=-54^{\circ}$, i.e., the injected current in sub-winding A2 is lagged $54^{\circ}$ to the sub-winding A1.

In the case of the elimination of the ninth harmonic, the relationship in (7) should be respected

$$
\phi-\delta=(2 k+1) \pi, \text { with } k_{9}=0 .
$$

However, the obtained angle $\delta$ from (5) and (7) cannot be achieved practically due to the condition of the integral multiple of the slot angle.

The proposed new winding configuration is shown in Fig. 2(a), which consists of two sub-winding groups: A1 and A2 and shifted by seven slots in the anti-clockwise direction.

\section{Supply Strategy of the New Winding}

The phase difference of the injected currents between the two sub-windings can be obtained by using two five-leg voltage source inverter (VSI) inverter but also in the precise case by achieving a star and pentagon connection between the windings as shown in Fig. 2(b). In a five-phase machine supplied in steady-state operation, the shift angle between two successive voltages is effectively $\left(180^{\circ}-360 / 5\right) / 2=54^{\circ}$. To keep the balance MMF distribution between these two subwindings, the number of turns of $\mathrm{A} 1$ is equal to $(\sqrt{5} / 2)$ times of the one of A2. Meanwhile, the section of the conductor should be also adjusted in the same ratio to have the same current density.

\section{Winding Factors and MMF Analysis}

For the new winding layout, the winding distribution coefficient $k_{\mathrm{d}}=1$ and a short-pitch coefficient $k_{\mathrm{p}}=0.9877$, and the winding factor is 0.988 instead of 0.9755 for the initial layout. Hence, the higher flux linkage and the higher torque density can be obtained with the new layout.

The main advantage of the new winding configuration is the elimination of selected space harmonics of MMF, while the short-end characteristic of FSCW is kept. Using the theory of winding functions, Fig. 3 shows the comparison of the MMF 


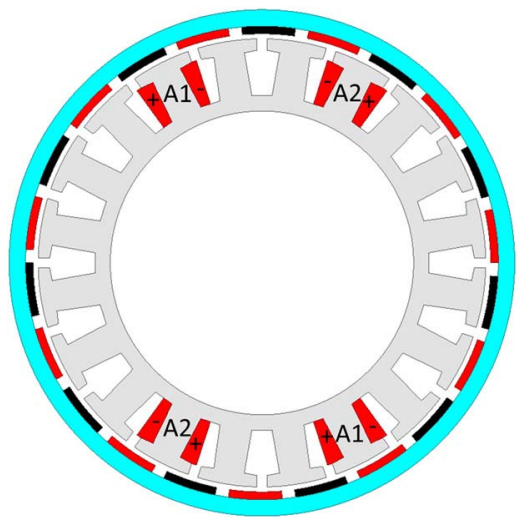

(a)

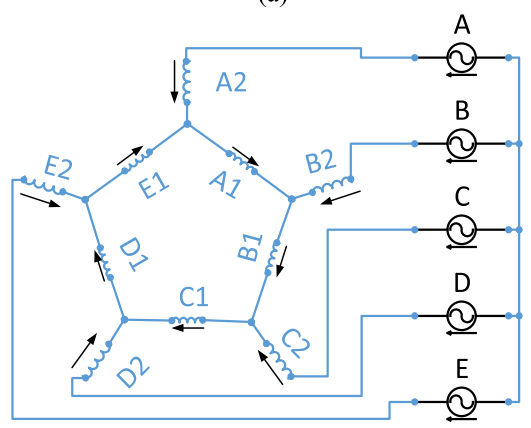

(b)

Fig. 2. 5-phase/20-slots/22-poles new winding. (a) New winding layout. (b) Supply strategy.

TABLE I

Main SPECIFICATIONS OF THE Two Machines

\begin{tabular}{|c|c|c|}
\hline Parameters & $\begin{array}{c}\text { Conventional } \\
\text { winding }\end{array}$ & $\begin{array}{c}\text { New } \\
\text { winding }\end{array}$ \\
\hline Rated power $(\mathrm{kW})$ & 1.45 & 1.45 \\
\hline Rated speed $(\mathrm{rpm})$ & 600 & 600 \\
\hline $\begin{array}{c}\text { Injected current density } \\
\left(\mathrm{A} / \mathrm{mm}^{2}\right)\end{array}$ & 5 & 5 \\
\hline Stator diameter $(\mathrm{mm})$ & 177 & 177 \\
\hline Stator yoke thickness $(\mathrm{mm})$ & 6 & 6 \\
\hline stack length $(\mathrm{mm})$ & 30 & 30 \\
\hline Rotor diameter $(\mathrm{mm})$ & 200 & 200 \\
\hline Rotor yoke thickness $(\mathrm{mm})$ & 6.5 & 6.5 \\
\hline Magnet thickness $(\mathrm{mm})$ & 3 & 3 \\
\hline Magnet width (mm) & 20.7 & 20.7 \\
\hline Coil turns around tooth & 50 & $59 / 50$ \\
\hline
\end{tabular}

wave and the harmonic spectrum between the two winding configurations. It can be seen that the first sub-space harmonic of the new winding is eliminated, the 11th one is slightly increased, and the total harmonic distortion (THD) is reduced by $2.2 \%$. The method has been presented for a particular five-phase machine but it can be used for other multiphase machines.

\section{Performance Evaluation Using FEM}

\section{A. Machine Design}

To verify the previous analysis, the 5-phase/20-slot/22-pole machines with both winding layouts are designed and analyzed using FEM. Table I presents the main specifications of the machine.

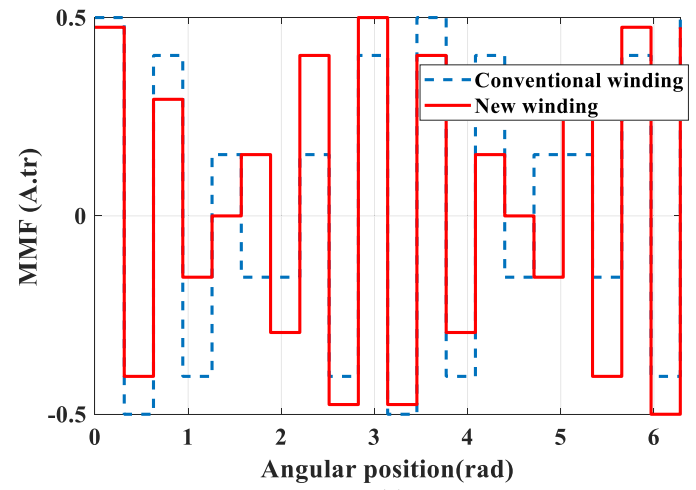

(a)

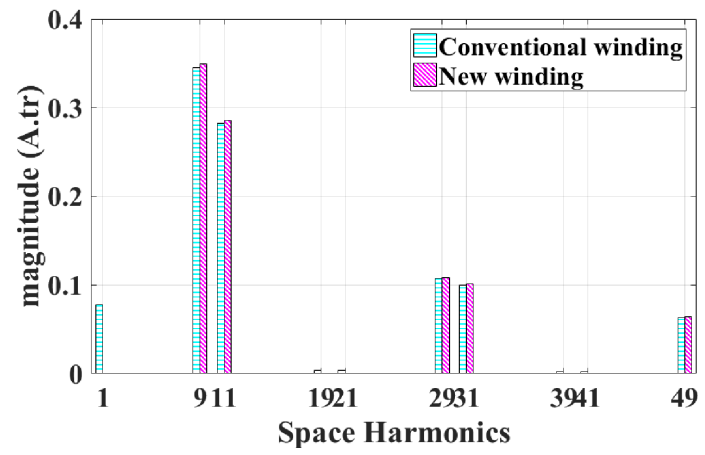

(b)

Fig. 3. Comparison of MMF waves and harmonics. (a) MMF wave. (b) MMF harmonics.

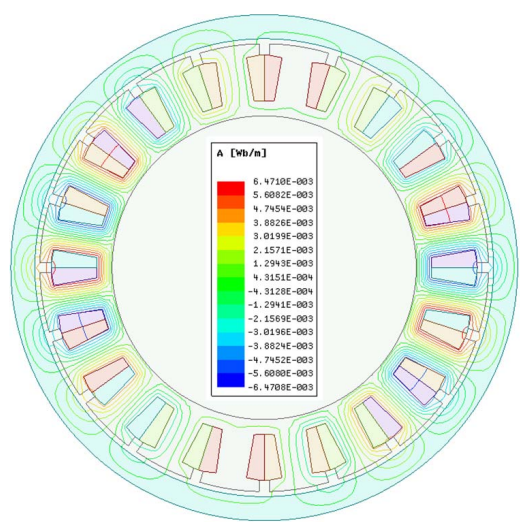

Fig. 4. Flux line distribution with the new winding layout.

\section{B. Comparison of Winding-Produced Air-Gap Flux Density and Spectrum}

Fig. 4 shows the winding flux line distribution of the proposed machine. To remove the interference of the rotor magnetic field on the MMF of the windings, the PMs on the rotor are considered as laminated iron.

The flux density of the two machines under no-load is shown in Fig. 5. Only one flux density is shown due to the two are the same because the two machines have a similar rotor except for coil turns.

The MMF harmonic spectrum can be verified by analyzing the winding produced air-gap flux density [19]. The waveforms and the harmonic spectrum of the two configurations are compared in Fig. 6. It can be seen that the first sub-order space harmonic is eliminated and the THD is improved by $2.1 \%$. Hence, similar results are obtained compared to the ones obtained by winding function theory in Section II-C. 


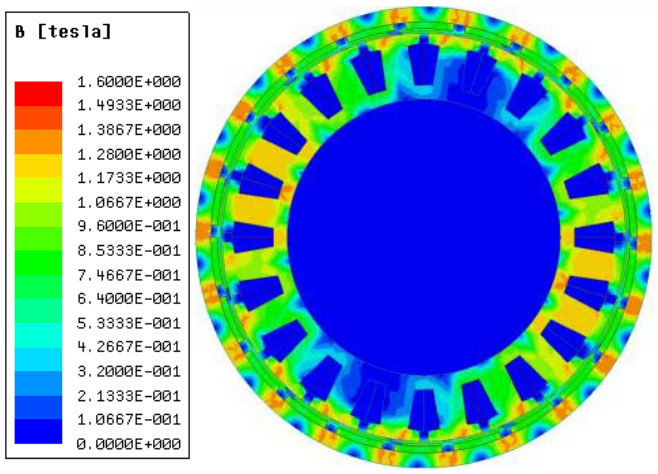

Fig. 5. Flux density of two machines under un-load.

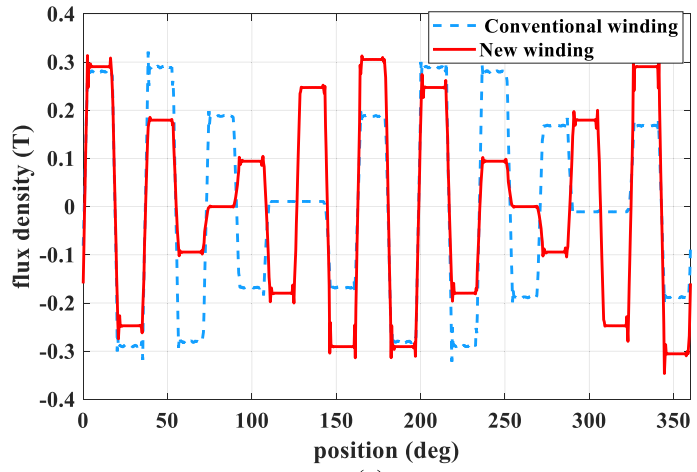

(a)

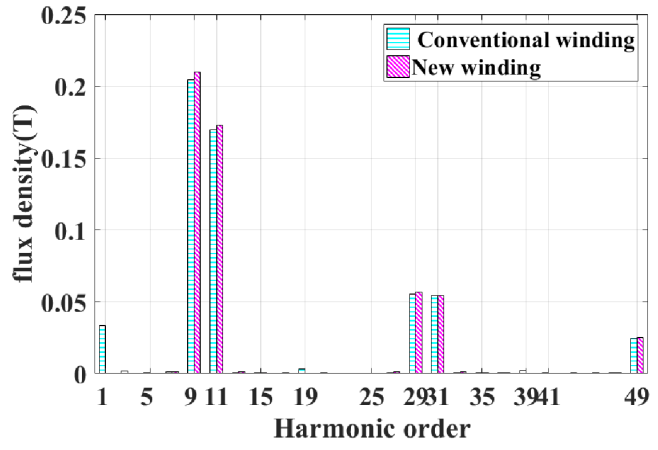

(b)

Fig. 6. Air gap flux density waves and harmonics without PMs. (a) MMF wave. (b) MMF harmonics.

\section{Back Electromagnetic Force}

The FEM predicted back electromagnetic forces (EMFs) of the conventional and the proposed new windings are shown in Fig. 7(a). It can be seen that the same value of back EMF is obtained for both configurations (53.14 and $53.08 \mathrm{~V}$ for the conventional and the proposed new windings, respectively), which can avoid the disadvantage of the conventional stator shift technique. The back-EMFs of the two sub-windings of the new winding are shown in Fig. 7(b). The different values are obtained due to the different number of turns, which can keep the balance MMF distribution between the two sub-windings with the current supply strategy shown in Fig. 2(b).

\section{Comparison of PM Loss and Efficiency}

The PM losses of the two machines at rated speed (600 r/min) and $2100 \mathrm{r} / \mathrm{min}$ speed are calculated, respectively, and shown in Fig. 8. It can be seen that there are less PM losses for the proposed winding due to the less parasite

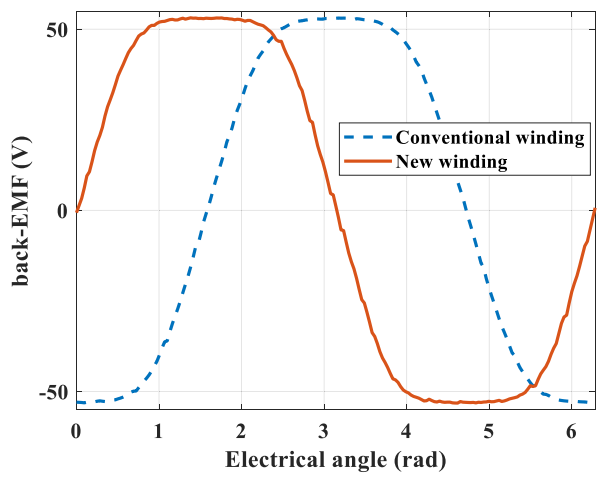

(a)

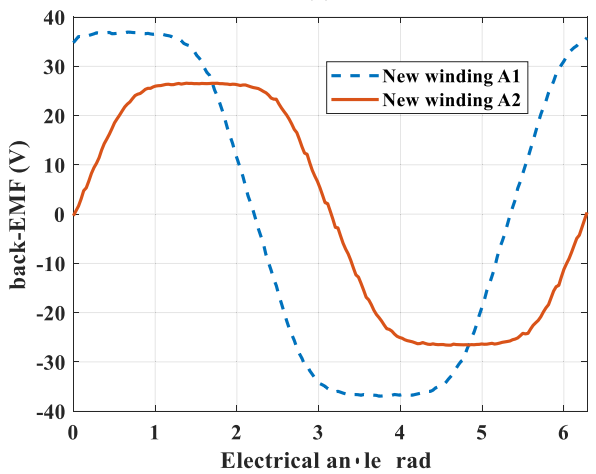

(b)

Fig. 7. Back-EMFs at $600 \mathrm{r} / \mathrm{min}$. (a) Comparison of the back EMF of two machines under no-load. (b) Comparison of the back EMF of two subwindings under no-load with $\sqrt{5} / 2$ ratio.

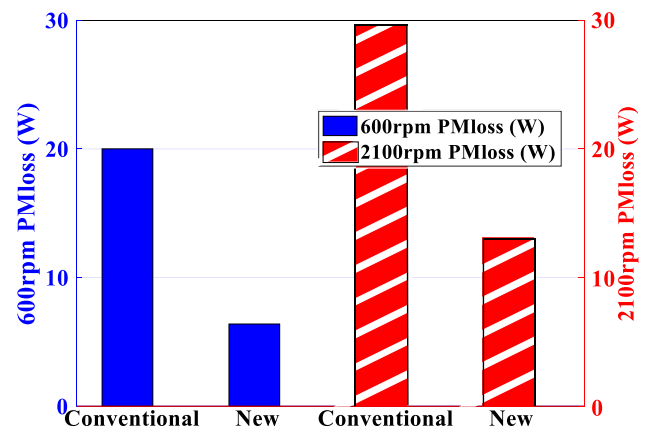

Fig. 8. PM loss at 600 and $2100 \mathrm{r} / \mathrm{min}$.

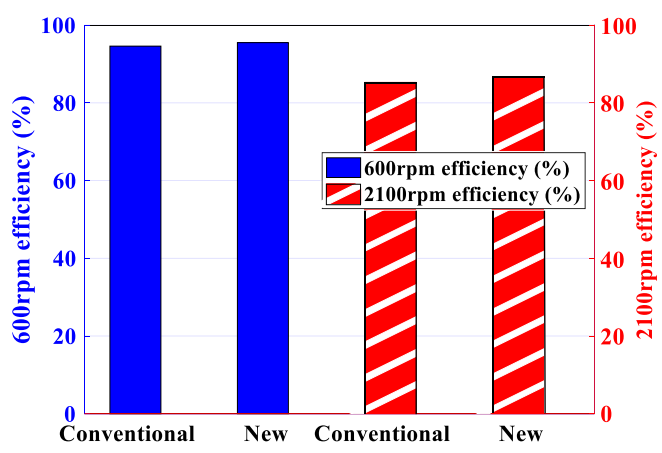

Fig. 9. Comparison of efficiency.

MMF harmonics, which shows the effectiveness of the new method for winding design and also the advantages of the new structure of the winding.

Fig. 9 shows the efficiency of the two machines at rated speed $(600 \mathrm{r} / \mathrm{min})$ and $2100 \mathrm{r} / \mathrm{min}$ speed, under the same 


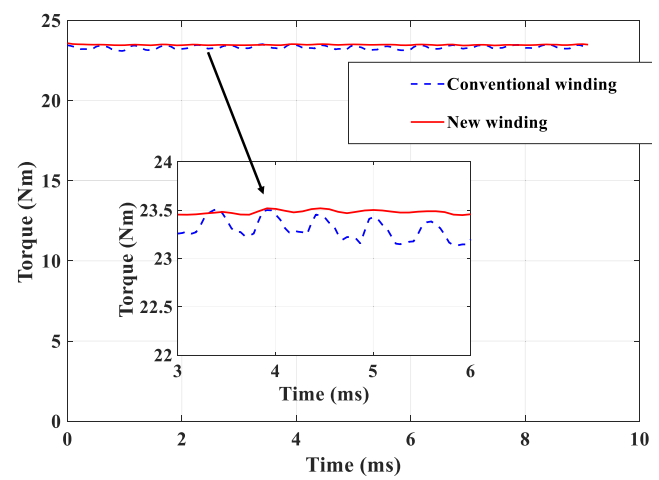

Fig. 10. Comparison of electromagnetic torque.

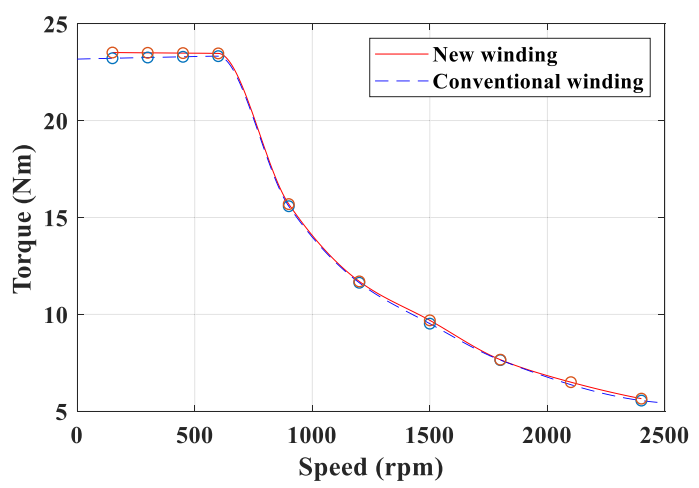

Fig. 11. Comparison of torque-speed curves.

injected current, respectively. It can be seen that the efficiency in both speeds has been improved. At the $2100 \mathrm{r} / \mathrm{min}$ speed, the efficiency has increased from $85.3 \%$ to $86.5 \%$.

\section{E. Electromagnetic Torque Characteristic}

Fig. 10 shows the electromagnetic torque characteristics with the same current density injection $J=5 \mathrm{~A} / \mathrm{mm}^{2}$. It can be noted that the average torque is increased by $1 \%$ and the torque ripple is reduced by $60 \%$ with the new winding layout.

Fig. 11 shows the torque-speed curves under the same condition. It can be noted that with the new winding layout, the average torque is slightly increased during the entire operating range.

\section{CONCLUSION}

In this article, a novel 5-phase/20-slot/22-pole winding topology is proposed by a stator shift technique combined with a star/pentagon winding connection. Compared to the conventional configuration, the first harmonic of MMF in the new winding is eliminated. Moreover, the non-overlapping characteristics of FSCW are kept. The winding factor of new winding is improved, and the THD of MMF is reduced by $2.1 \%$. The output torque is increased by $1 \%$, and the torque ripple is reduced by $60 \%$. The FEM results proved the effectiveness of the proposal.

\section{ACKNOWLEDGMENT}

This work was supported by the Natural Science Foundation of Shandong Province of China through the Project under Grant ZR2020ME207.

\section{REFERENCES}

[1] A. M. El-Refaie, "Fractional-slot concentrated-windings synchronous permanent magnet machines: Opportunities and challenges," IEEE Trans. Ind. Electron., vol. 57, no. 1, pp. 107-121, Jan. 2010.

[2] J. Gong, H. Zahr, E. Semail, M. Trabelsi, B. Aslan, and F. Scuiller, "Design considerations of five-phase machine with double p/3p polarity," IEEE Trans. Energy Convers., vol. 34, no. 1, pp. 12-24, Mar. 2019.

[3] N. Bianchi, S. Bolognani, M. D. Pre, and G. Grezzani, "Design considerations for fractional-slot winding configurations of synchronous machines," IEEE Trans. Ind. Appl., vol. 42, no. 4, pp. 997-1006, Jul. 2006.

[4] B. Aslan, E. Semail, J. Korecki, and J. Legranger, "Slot/pole combinations choice for concentrated multiphase machines dedicated to mildhybrid applications," in Proc. 37th Annu. Conf. IEEE Ind. Electron. Soc. (IECON), Vienna, Austria, Nov. 2011, pp. 3698-3703.

[5] B. Aslan, E. Semail, and J. Legranger, "General analytical model of magnet average eddy-current volume losses for comparison of multiphase PM machines with concentrated winding," IEEE Trans. Energy Convers., vol. 29, no. 1, pp. 72-83, Mar. 2014.

[6] G. Dajaku, S. Spas, and D. Gerling, "Advanced optimization methods for fractional slot concentrated windings," Electr. Eng., vol. 101, no. 1, pp. 103-120, Apr. 2019.

[7] P. B. Reddy, K.-K. Huh, and A. M. EL-Refaie, "Generalized approach of stator shifting in interior permanent-magnet machines equipped with fractional-slot concentrated windings," IEEE Trans. Ind. Electron., vol. 61, no. 9, pp. 5035-5046, Sep. 2014.

[8] S. Zhu, T. Cox, Z. Xu, and C. Gerada, "Novel 24-slots 14-poles fractional-slot concentrated winding topology with low-space harmonics for electrical machine," J. Eng., vol. 2019, no. 17, pp. 3784-3788, Jun. 2019.

[9] A. S. Abdel-Khalik, S. Ahmed, and A. M. Massoud, "A six-phase 24-slot/10-pole permanent-magnet machine with low space harmonics for electric vehicle applications," IEEE Trans. Magn., vol. 52, no. 6, pp. 1-10, Jun. 2016.

[10] V. I. Patel, J. Wang, W. Wang, and X. Chen, "Six-phase fractionalslot-per-pole-per-phase permanent-magnet machines with low space harmonics for electric vehicle application," IEEE Trans. Ind. Appl., vol. 50, no. 4, pp. 2554-2563, Jul. 2014.

[11] K. Wang, Z. Q. Zhu, and G. Ombach, "Synthesis of high performance fractional-slot permanent-magnet machines with coil-pitch of two slotpitches," IEEE Trans. Energy Convers., vol. 29, no. 3, pp. 758-770, Sep. 2014.

[12] P. Zheng, F. Wu, Y. Lei, Y. Sui, and B. Yu, "Investigation of a novel 24-slot/14-pole six-phase fault-tolerant modular permanentmagnet in-wheel motor for electric vehicles," Energies, vol. 6, no. 10, pp. 4980-5002, Sep. 2013.

[13] G. Dajaku and D. Gerling, "A novel 24-slots/10-poles winding topology for electric machines," in Proc. IEEE Int. Electr. Mach. Drives Conf. (IEMDC), Niagara Falls, ON, Canada, May 2011, pp. 65-70.

[14] N. Bekka, M. H. EI Zaim, N. Bernard, and D. Trichet, "A novel methodology for optimal design of fractional slot with concentrated windings," IEEE Trans. Energy Convers., vol. 31, no. 3, pp. 1153-1160, Sep. 2016.

[15] N. Tang and I. P. Brown, "A systematic approach for developing electric machine windings with suppressed MMF space harmonics," Electr. Power Compon. Syst., vol. 45, no. 20, pp. 2327-2338, Dec. 2017.

[16] N. Tang and I. P. Brown, "Framework and solution techniques for suppressing electric machine winding MMF space harmonics by varying slot distribution and coil turns," IEEE Trans. Magn., vol. 54, no. 5, pp. 1-12, May 2018.

[17] M. V. Cistelecan, F. J. T. E. Ferreira, and M. Popescu, "Three phase tooth-concentrated multiple-layer fractional windings with low space harmonic content," in Proc. IEEE Energy Convers. Congr. Expo., Sep. 2010, pp. 1399-1405.

[18] W. Zhao, J. Zheng, J. Ji, S. Zhu, and M. Kang, "Star and delta hybrid connection of a FSCW PM machine for low space harmonics," IEEE Trans. Ind. Electron., vol. 65, no. 12, pp. 9266-9279, Dec. 2018.

[19] Y. Sui, P. Zheng, F. Wu, B. Yu, P. Wang, and J. Zhang, "Research on a 20-slot/22-pole five-phase fault-tolerant PMSM used for fourwheel-drive electric vehicles," Energies, vol. 7, no. 3, pp. 1265-1287, Mar. 2014.

[20] J. Marault, F. Gillon, M. Hecquet, and A. Tounzi, "Optimization of the MMF spatial harmonic content to design electrical machine winding," Int. J. Appl. Electromagn. Mech., vol. 64, pp. S99-S114, Jan. 2021. 